\title{
Chapter 2 \\ Points of Departure: Geographical, Historical and Theoretical Contexts
}

\begin{abstract}
A young French guy passes an old immigrant on the street, and wonders what the hell he's still doing here. But he doesn't know that it was the old immigrant who built the street, who built that very pavement. It's very important that people know what we immigrant workers did.
\end{abstract}

Interview with Habib, 65, a hostel resident from Oran, Algeria.

This chapter situates the late-in-life mobility of hostel residents in its geographical, historical, and theoretical contexts. As noted in Chap. 1, the vast majority of hostel residents hail from France's former colonies in North and West Africa. Section 2.1 charts the geography and history of migration from these areas. Section 2.2 pursues the historical theme by elaborating how France's migrant worker hostel accommodation came into being in the late 1950s and subsequently developed. While originally envisaged for a young working-age population, the migrant hostels now host an ageing cohort of men who, defying expectation, do not return definitively to their families at retirement. Section 2.3 sketches four distinct theoretical frameworks which have the potential to explain this counter-intuitive behaviour: these are the new economics of labour migration, structuralism, transnationalism, and social systems theory. I conclude the chapter with a discussion of the methodological implications which follow from the study's stated aim to explain hostel residents' late-in-life mobility.

\subsection{Contexts of Emigration}

As noted, the hostels house a population of predominantly North African and West African origins. Although developing at different times, flows of migrants from these regions to France display significant similarities. For the North African context I will focus on flows from Algeria and Morocco, since all of my North African 
respondents originated from these two countries. ${ }^{1}$ For the West African context I will confine my discussion to the case of a single ethnic group, the Soninke, inhabiting a triangle of borderland where the frontiers of present-day Senegal, Mauritania and Mali intersect (see Figs. 2.1, 2.2, and 2.3). All of my West African respondents hailed from these three sending countries and with few exceptions identified as Soninke. The Soninke dominated flows from West Africa to France up until the 1970s (Manchuelle 1997). Early flows in the Algerian case (ca. 1905-1945) and the Moroccan case (ca. 1914-late 1950s) are also dominated by a single ethnic group from a clearly-defined geographical region, respectively the Berbers of mountainous Kabylia (to the east of the capital Algiers) and the Chleuh (also Berber-speaking) of the Souss in southern Morocco (Lacroix 2005; Manchuelle 1997).

Given the heavy boot-print of French colonisation in these three sending regions, many scholars have subscribed to the view that emigration was a movement of 'uprooted' populations reacting to tumultuous change (Amin 1974; Bathily 1972; Silverstein 2004; Sayad 2006). In all three cases, however, contemporary scholars have been at pains to demonstrate that initial flows were not a response to the colonial violence and economic disruption (e.g. taxation, forced imposition of a market economy) perpetrated by the colonists on local populations (Lacroix 2005; MacMaster 1997; Manchuelle 1997). Instead, migration from these regions (be it internal or international) was at the outset a consequence of climatic and topographic conditions. ${ }^{2}$ All three sending regions experienced short growing seasons, and in each case there were few non-agricultural employment opportunities locally, hence the resort to migration to pursue alternative livelihoods in the off-season. In the nineteenth century, this livelihood-based mobility, whether through trade, soldiering or agricultural employment, quickly brought the three ethnic groups into contact with the French colonists, making them privileged interlocutors. It is no surprise therefore that these ethnic groups dominate the first emigration cohorts from their respective countries.

Turning to Morocco first, emigration was for long the prerogative of the Berberspeaking Chleuh ethnic group, from the mountainous Souss region, covering the provinces of Agadir, Taroudant and Tiznit (see Fig. 2.1). Significant emigration from Morocco to France began during WWI. By 1929, of 21,000 Moroccans in France, 95\% were from the Souss (Lacroix 2005). Lacroix sees Chleuh migration as "anything but an exit" provoked by the lack of natural resources in the Souss or a crisis in the social and economic order there (2005: 27). Rather emigration was based on long-standing pre-colonial traditions of livelihood mobility to Northern

\footnotetext{
${ }^{1}$ Tunisians are also prominent in the hostel population: as of the 1999 census 6725 Tunisians resided in this accommodation (Renaut 2006). However, it so happened that there were very few Tunisians resident in the hostels I visited during my fieldwork.

${ }^{2}$ The Soninke lands border the southern fringes of the Sahara Desert and the climate there is typical of Sahelian zones, with an annual short rainy season providing a regular if reduced source of water for cultivation purposes. The Kabyle and Chleuh peoples inhabit mountainous regions of Algeria and Morocco respectively. Regular rainfall and sunshine permit a wide range of crops to be grown, but the mountainous topography prevents large yields.
} 


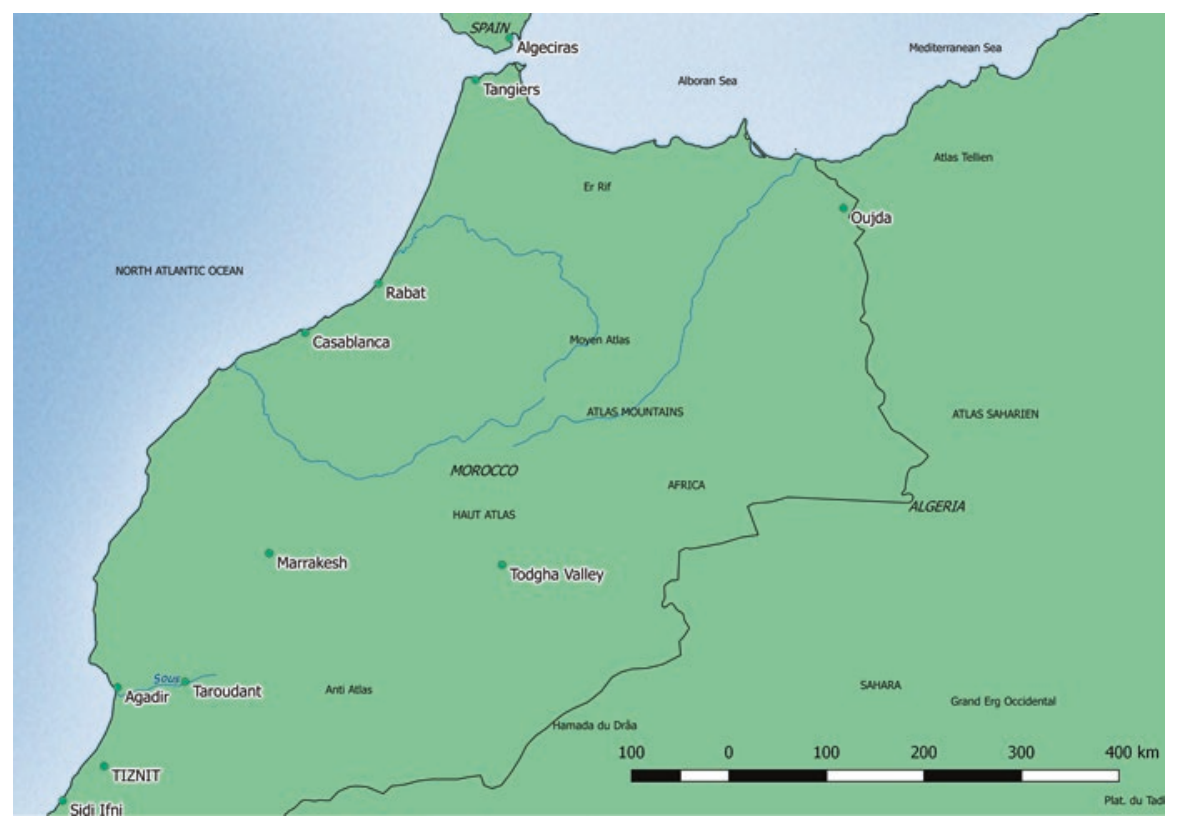

Fig. 2.1 Map of Morocco, showing the main towns and regions cited in the book. Map made with Natural Earth free vector and raster map data and created using QGIS free and open-source software (http://www.qgis.org/en/site/index.html)

and Western Morocco during the agricultural off-season, engaging in trade, military service or seasonal agriculture (Lacroix 2005; de Haas 2007). The end of WWII is a key moment in the history of migration to France, and not only from Morocco. In 1946, in response firstly to the vast rebuilding effort which was required after the war and secondly to France's worrying demographic position due to low birth rates, an open-door immigration policy was initiated. The French government, like other war-torn European states, had a "cultural preference" for immigrants of European origin (Viet 1998: 21-2), but labour supply (notably from Spain and Italy) could not match the demands of French industry. Solutions were soon sought in the colonial territories of North Africa. Recruiting agents hired migrant workers 'on the spot' in the main towns of the region, often on marketdays. ${ }^{3}$ The 'candidates' for emigration (including some of those interviewed for this book: see Chap. 4 epigraph) were selected in the souks (markets) and conveyed by bus, boat and train directly to the mines of northern France. A second route into France, less official than the recruitment organised by the mining companies, was to enter as a tourist and then secure paid employment, which in turn secured a residence permit. Knowledge about job vacancies was relayed by friends and family already in France. Following Moroccan

${ }^{3}$ The most famous of these agents, Félix Moura, supervised the hiring of 78,000 people between 1956 and 1977 (Lacroix 2005). 


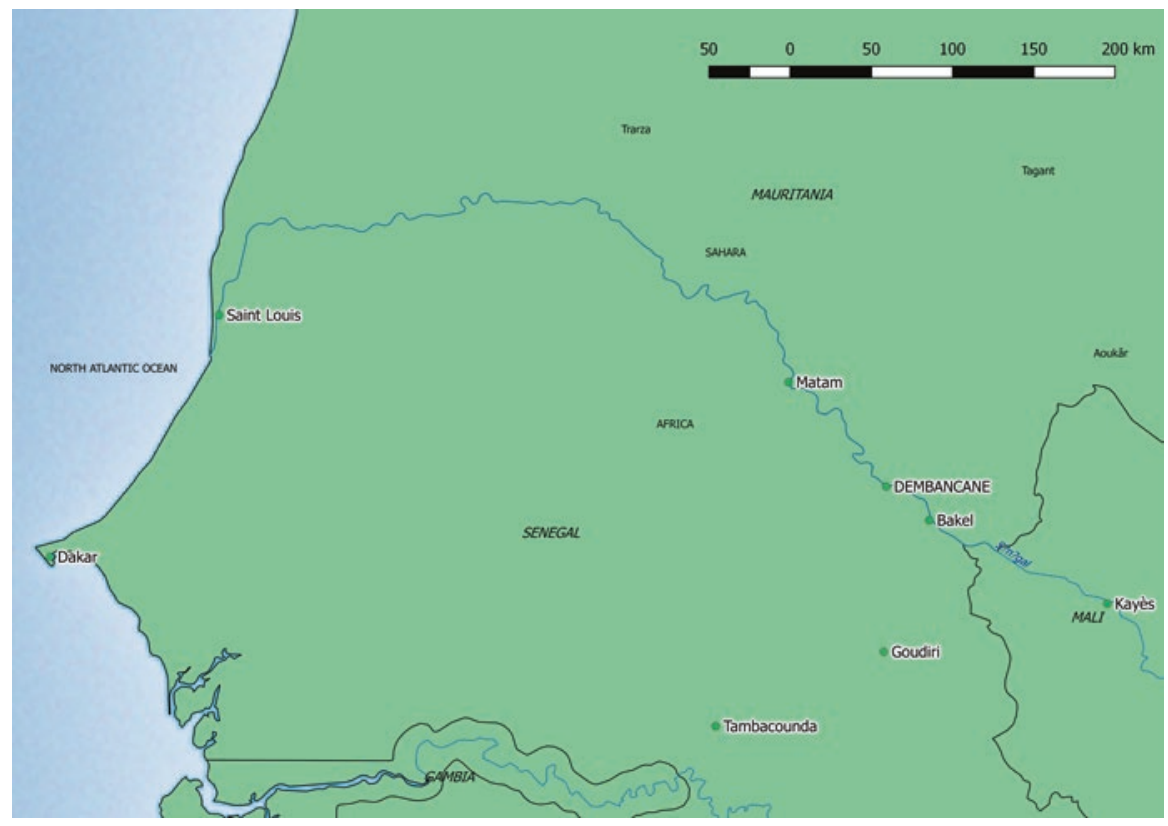

Fig. 2.2 Map of Senegal, showing the main towns and regions cited in the book. Map made with Natural Earth free vector and raster map data and created using QGIS free and open-source software (http://www.qgis.org/en/site/index.html)

independence in 1956, the newly sovereign government began to encourage emigration from the rebellious Rif region in the North (de Haas 2007). Nonetheless, emigration from the Souss remained very high: in 1980, "one in every five people of working age from the Provinces of Tiznit, Agadir and Taroudant worked abroad" (Lacroix, 2005: 36).

Migration from Soninke lands to other parts of West Africa has a far longer history than Soninke emigration to France, which only began in the mid-1950s. The Soninke inhabit a narrow wedge of territory flanking the Upper Senegal River Valley, beginning around Matam in Senegal and spreading south-east through Bakel into Mali and parts of Mauritania, extending past the city of Kayès (see Fig. 2.2). During the eighteenth century, the Soninke were "the most important slave owners and slave traders in West Africa" (Manchuelle 1997: 145) and became the privileged partners of the French in this trade. From the mid-nineteenth century, Soninke migrants also travelled to Gambia for seasonal agriculture, in particular the harvesting of groundnuts. A third avenue of labour migration was more military in character, with young Soninke men, especially the sons of more prestigious families, finding employment as armed guards (laptots) on French-owned boats trading up and down the Senegal River. Contacts with French traders gave these men advance notice of job opportunities further afield. A major shift in Soninke migration is evi- 
dent from the 1930s, and especially after WWII, changing from seasonal shortdistance moves to pluriannual and eventually life-long emigration, initially to Dakar and other major urban centres, and then to France. The creation of a deep water port at Dakar saw laptots switching to ocean-going vessels. By 1930, the Soninke sailors were the most numerous African group transiting the port of Marseille. Employment on French ships in time led to employment in France itself, beginning in the mid1950s. The Algerian war accelerated the arrival of Soninke in France. In 1956, the French authorities imposed visa controls for Algerians, only lifted in 1962 by the Evian accords. Hence French industry's call for a more diverse foreign workforce, to which the Soninke migrants readily responded (Manchuelle, 1997; Adams, 1977). Indeed, François Manchuelle in the title to his 1997 book characterises the Soninke in the period 1848-1960 as 'willing migrants'. By 1968, 85\% of West Africans in France were Soninke (Manchuelle 1997). However, from the 1970s Mahamet Timera (1996) sees a shift from 'willing' to 'uprooted' migration, firstly due to the global recession, and secondly due to successive droughts (1968-74). These two developments led to greater dependence of migrants' families on remittances (Manchuelle 1997). Manchuelle notes that "the drought may have left few other options to the Soninke apart from migration" (1997: 212). Adrian Adams, in her fascinating account of Soninke village life, also argues that from 1970 emigration was a "movement of self-defence" (1977: 97).

Last but certainly not least is the Algerian context. Indeed, the migration of Algerians constitutes the numerically most significant population movement into France of the twentieth century. Most observers locate the beginning of Algerian emigration to France around 1910 (Sayad 2006; MacMaster 1997). Travel restrictions were partially lifted in 1904, and then completely abolished in 1914. Counterintuitively, it was in those areas least affected by colonial violence and uprooting that most emigration took place, particularly the mountainous Kabylia region east of Algiers (see Fig. 2.3) which was not suited to commercial agricultural exploitation. By contrast, emigration from the fertile coastal plain (to the south-west of Algiers) which witnessed the most destructive colonial intrusions - was strongly discouraged by the authorities because the plain-dwellers constituted a cheap and compliant local labour force (MacMaster 1993, 1997). As in the Moroccan and Soninke cases, Kabyle emigration was a response to local climatic and topographic conditions and the resulting lack of employment opportunities outwith the short agricultural season. Thus, the Kabyle flows to France were primarily seasonal or temporary sojourns of at most a few years prior to returning to the village of origin and the family lands. In terms of numbers departing, WWI was a significant juncture and provided many Algerians with their first experience of France, either as soldiers or as workers in munitions factories (a slim majority were volunteers not conscripts). Following WWI, many Kabyles decided to return to the Métropole on a seasonal or temporary basis. By 1923, a Berber-speaking Kabyle was 16 times more likely to emigrate than an Arabic-speaking inhabitant of the coastal plain (MacMaster 1997). 


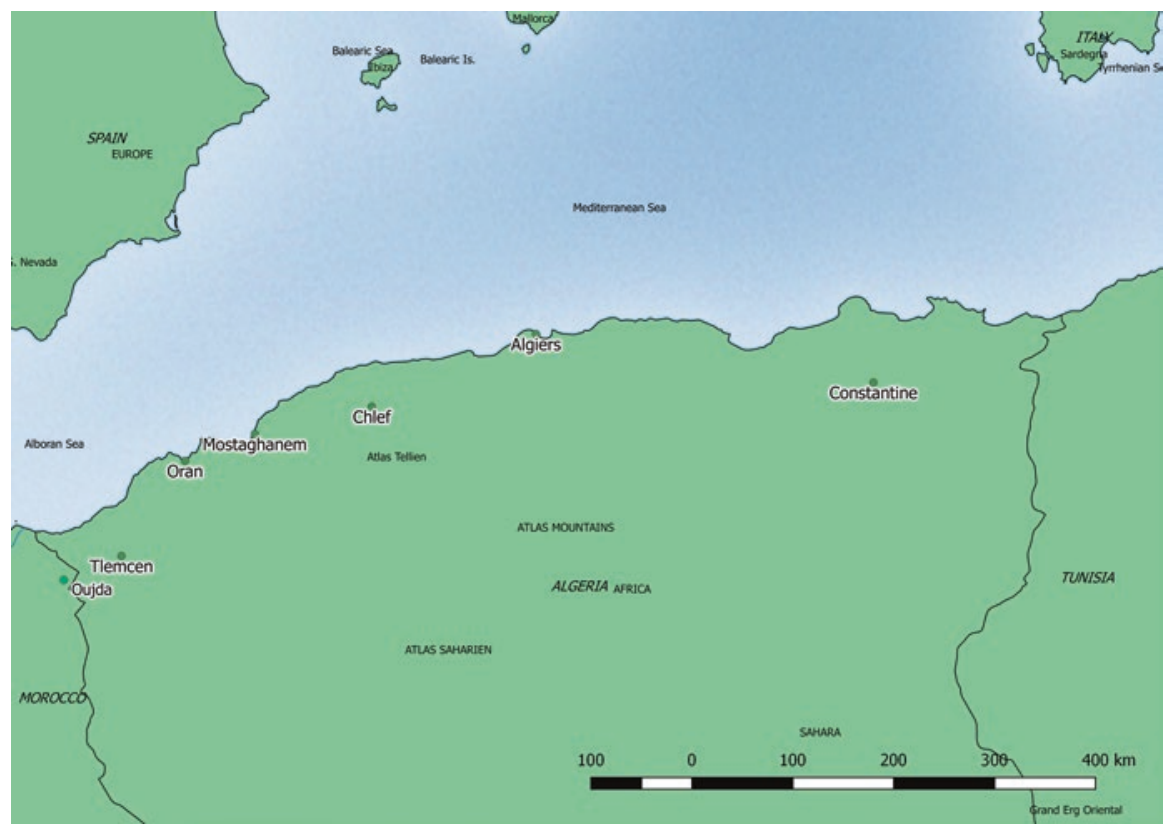

Fig. 2.3 Map of Algeria, showing the main towns and regions cited in the book. Map made with Natural Earth free vector and raster map data and created using QGIS free and open-source software (http://www.qgis.org/en/site/index.html)

Yet the aftermath of WWII is arguably a more important turning point than WWI. A travel blockade had been in effect between Algeria and France between 1942 and 1945. With the implementation of the open-door immigration policy in 1946, the built-up pressure to emigrate from Algeria exploded. Importantly, the Kabyle pioneers were this time joined by the inhabitants of the coastal plain, who were fleeing desperate poverty and colonial dispossession. This resulted in a massive increase in the Algerian population in France, which doubled in 4 years from 120,000 in 1949 to 240,000 in 1953 (Viet 1998). The following year, 1954, would see the opening shots fired in the Algerian War of Independence. The importance of this conflict in France's recent political history is hard to overstate, and its effects continue to resonate today. However it is in the stark form of the migrant worker hostels (Fig. 1.1) that the Algerian War has left one of its most concrete and lasting marks on France.

\subsection{The Three Ages of the Hostels: Sonacotral-Sonacotra-Adoma}

For any newly-arrived migrant, quickly finding appropriate accommodation is a basic priority. Most often, this occurs through the mechanisms of the private housing market, according to a logic of supply and demand. More rarely, employers may 
be mandated to organise housing for their foreign employees, as occurred for example in West Germany in the 1960s and 1970s (Bernardot 1999; Castles et al. 1984). In neighbouring France, however, the state deemed it necessary to intervene in this sector and invested a great deal of money and administrative energy in the creation of hostel accommodation solely for labour migrants. It was Algerian workers who were the initial targets of the migrant worker hostel policy, implemented as it was by the state-financed Sonacotral company (Société nationale de construction de logements pour les travailleurs algériens or National Housing Construction Company for Algerian Workers), created in 1956. While other hostel companies have existed, the case of Sonacotral will be treated as exemplary here because it was the first and largest such company and because the changes it has experienced have been reproduced later in other hostel companies.

In the present section covering the development of this very specific form of housing I will distinguish between three key phases or 'ages', to paraphrase the landmark text of the French-Algerian sociologist of migration Abdelmalek Sayad ${ }^{4}$. The first age corresponds to the period 1956-1962, when Sonacotral specialised in housing Algerian workers only. The raison d'être of hostels at this time followed a security logic, as hinted in the conclusion to the previous section. The second phase begins in 1963, when Sonacotral's mission was expanded to cater not only for Algerians but for all migrant workers. The reorientation was reflected in a slightly modified and more generic name, Sonacotra (Société nationale de construction de logements pour les travailleurs). In this second period I argue that the guiding logic of the hostels was to reconcile the twin imperatives of restricting family reunification and maintaining a flexible labour market. This period also witnessed significant industrial unrest and political activism on the part of hostel residents. The third period commences in the early 1990s, heralding the most recent phase during which the company has sought to diversify its clientele to other precarious populations. This latest phase has been accompanied by a further name change. As of 2007, the company is called Adoma.

Sonacotral: "the Algerian War in Concrete" (1956-1962) Post-WWII labour immigration coincided with a severe housing shortage in French cities and towns. This shortage was due to three principal factors: war damage, substantial ruralurban migration, and insufficient production of new dwellings. In the immediate aftermath of WWII, housing was not a priority for the French government as its focus was rebuilding France's industrial infrastructure and economic base (Power 1993). With not enough habitable dwellings for the French-born population, it is no surprise that immigrant workers could not access the housing market. Instead, foreigners (and many French citizens too) had to get by as best they could, in the form of self-constructed shantytowns (bidonvilles) springing up on disused ground, often near industrial sites on the edge of the major conurbations - Paris, Lyon and Marseille. The poor hygiene conditions found in the shantytowns constituted a major public health risk, as an internal government memo from 1948 remarks: "the situation of the North Africans (...) is quite alarming (...) Many of them are tainted

${ }^{4}$ I am referring here to Sayad (1977) Les trois "âges" de l'émigration algérienne en France. Actes de la recherche en sciences sociales, 15(1), 59-79. 
with 'infectious illnesses' and the absence of hygiene as well as their cramming together in cramped spaces, multiplies the dangers of contamination" (cited in Atouf 2002: 63; author's translation). However, the bidonvilles were not officially acknowledged or reported in the press until the mid-1950s (Bernardot 1997; Hmed 2006). At that time the uppermost estimates put the total population in the shantytowns at 25,000 (Bernardot 1997). Contemporary scholars, however, put the true figure between 200,000 and 300,000 people (Power 1993; Lallaoui 1993: 44-5; in Bernardot 1997). Atouf (2002) cites sources which estimate that one third of all North Africans in France were living in slums or shantytowns as of 1953.

The housing crisis became a major preoccupation of the French government and the press somewhat later, in the mid-1950s, as my research at the Sciences-Po Press Archive underlined. A 1958 article in the newspaper La Croix is not unrepresentative of the moral panic which slum housing provoked:

In the matter of housing, [France] presents the undeniable characteristics of a prerevolutionary state. There exists now, in this country, the seeds of a revolt, sown and nurtured in the inhuman constraints of the slums. (...) This growing number of people in sub-standard housing, recruited from younger and younger classes who are less and less resigned, constitutes a stick of dynamite which only needs a spark to be set off. (Boissonnat 1958; author's translation).

One such potential spark was the insurrection in Algeria. Indeed, the Algerian War (1954-1962) was decisive in the genesis of the migrant worker hostels. The shantytowns were widely believed to provide substantial funds for the Algerian independence movement, spearheaded by the FLN (Front de libération nationale) (Boutaleb 2000; Petauton 2007; Viet 1999). The minutes of a government meeting in January 1956 give an inkling into the mindset of the public powers, conflating security concerns in Algeria with the 'problem' of housing North African workers in metropolitan France:

As regards the [housing] needs of the 300,000 North Africans, working or otherwise, in this country, the required effort remains considerable and yet peace in North Africa will perhaps depend on the solution which Metropolitan France will be able to find to the problem of housing for Algerian workers (Conseil économique 1956: 57; author's translation).

The ministries of Interior, on the one hand, and Work and Social Security, on the other, clashed over what this housing solution should be: the security rationale of the former prevailed (Bernardot 1997; Viet 1998). By directing the shantytown dwellers to a different type of accommodation, the French authorities believed they would be better able to fight against the "FLN contamination" in these marginal spaces where the forces of law and order feared to tread. Given the security risk posed by this population, ministers were persuaded that whatever the type of housing chosen to replace the shantytowns, it would have to incorporate a surveillance function.

Indeed, all historians of the hostels are unanimous on this point: its aims were to "group together the Algerians, to count and register them, and to put them under

\footnotetext{
${ }^{5}$ This phrase appears in the statutes of the Maison de l'Afrique du Nord housing association in Lyons, founded in 1952 and considered to be the blueprint for Sonacotral. See Hmed 2006: 90.
} 
surveillance in order to cut the artery which furnished the FLN with money" (Boutaleb 2000: 151; author's translation). Marc Bernardot describes the hostels memorably as "the Algerian War in concrete" (Bernardot 2001: 162; author's translation). What the Ministry of the Interior feared above all was the appearance of a second front to this rebellion composed of Algerian workers in Metropolitan France, starting in the numerous and hard-to-police bidonvilles. Given the war in Algeria, the authorities decided that the colonial population working in France should be kept away from the town centres, and that a policy of strict social and political control, amounting to a carceral control (Petauton 2007; Viet 1999), should be instituted for them.

Sonacotra: Provisional Housing for Provisional Workers? (1963-1992) The Algerian War came to an end in 1962. The following year Sonacotral underwent a change of name, becoming Sonacotra. This change signified the company's reorientation from housing Algerian workers only towards its new mission to provide housing for all migrant workers. ${ }^{6}$ In this second period, the rationale behind the state's continued tutelage of the company shifted from the security logic of surveillance to a labour market logic. In the early 1960s France found itself in the middle of a three-decade long economic boom, a period which would come to be known as Les trente glorieuses. To maintain economic growth, the country relied on a large influx of cheap, foreign and low-skilled labour to man the production lines in its factories and the building sites of its public infrastructure projects. At the same time, the French authorities wished to benefit from this influx of flexible low-cost labour without having to pay the indirect costs associated with it, namely the housing, schooling and healthcare costs of hosting the migrant workers' dependent family members. Employers also favoured hiring single foreign workers as such workers could be made redundant more easily than local employees, the latter having both economic and social ties to their locality and therefore more inclined to vehemently oppose mass redundancies. Thus, as Marc Bernardot argues, the hostels functioned as the housing side of a broader "labour force policy which had as its objective the limitation of the durable installation and family reunification of [migrant] workers" (Bernardot 1997: 12; author's translation). Similarly, Mireille Ginesy-Galano writes that one of the primary purposes of the hostels policy was to "prevent [migrant workers] taking root, that is to say, prevent their installation in France with their families" (Ginesy-Galano 1984: 282; author's translation). By keeping the rents as low as possible, the initiators of the hostel policy aimed to encourage the men to remain geographically single and send as much money as possible homewards, thus benefiting their families more than would have been the case had the latter come to live in France, where the cost of living was more expensive (Viet 1999).

More broadly, Abdelmalek Sayad argues that what dictated the approach of the public authorities above all was the notion of migrants as temporary workers par

\footnotetext{
${ }^{6}$ Sonacotra stands for Société nationale de construction de logements pour les travailleurs (National Housing Construction Company for Workers).
} 
excellence, with only their labour to offer, "all their other properties being only ever impedimenta to be treated at the least cost" (Sayad 2006: 129; author's translation). This goes especially for the type of accommodation accorded these labourers, the migrant worker hostel, which Sayad describes as "provisional lodging... for a provisional resident, as this is how the immigrant is always imagined" (Sayad 2006: 82). This short-term vision materialised in the very fabric of the dwellings, described by Ginesy-Galano variously as "sub-housing" or "travesties of housing" (simulacres de logement) (1984: 1, 280). The design on which the first Sonacotral hostels were based is known as the F6 model: family apartments of five bedrooms plus a kitchen/dining area (hence F6) were reconfigured into living quarters for ten men. This was done by dividing each bedroom in half with a light plasterboard partition, creating in total ten tiny rooms of approximately 4.5 square metres each. ${ }^{7}$ As late as $1999,40 \%$ of accommodation in the hostel sector was formed either of individual rooms of 4.5 square metres or shared dormitories (Bernardot 2008: 259). More widespread was the larger F1/2 model which also used light partitions to divide rooms, resulting in housing units of 7.5 square metres. However this is still significantly smaller than the minimum standard of 9 square metres which was legally required in other social housing of the time.

The material inadequacies of the accommodation had considerable negative impacts on the wellbeing of hostel residents. Indeed the attention of psychiatrists was quickly alerted to the effects on residents of the cramped living quarters (Ben Jelloun 1977). The flimsiness of the room partitions manifested itself in a lack of sound-proofing and privacy which was a major nuisance according to surveys of residents (Ginesy-Galano 1984). A further denial of privacy consisted in the very strict regulations regarding good order and morality which were imposed on residents (Viet 1999). For example, hostel staff were entitled to enter residents' rooms at any time of the day or night, without prior permission, in order to suppress all manner of supposed ills, including political activity, gambling, and overnight stays of non-residents (especially females). Guilty parties were liable to summary expulsion. To ensure the application of these diktats required particular skills on the part of the staff. In the 1960s and 1970s, Sonacotra exhibited a very clear preference for former military men to fill the role of hostel director, particularly those who had taken charge of North African recruits during colonial campaigns (Sayad 2006). These ex-soldiers were able to apply their "sense of command, knowledge of the 'morals' and 'psychology' of the residents [and] knowledge of Arabic" to a new institutional setting (ibid: 128).

The objectively poor living conditions and infringements on private life described above were at the heart of the contestation which shook Sonacotra to its core during the 1970s: the 'rent strike' of 1973-1981. This period was a time of wider industrial unrest in which migrant workers were strongly implicated and, as the longestrunning political mobilisation of foreigners in France, the Sonacotra rent strike has become emblematic of the era (Bernardot 2008; Peace 2015; Pitti 2008). Beginning

\footnotetext{
${ }^{7}$ The assumption of the authorities was that the hostels would quickly be convertible back to (more spacious) social housing for French families (Gallou and Rozenkier 2006: 64).
} 
in 1973 at two hostels in Bobigny near Paris, residents began withholding payment of their rent in protest over three issues: the miniscule rooms, the oppressive interior regulations, and the elevated rents (Pitti 2008). The revolt quickly spread throughout the Paris region, eastern France, and to a lesser extent around Lyon and Marseille (Bernardot 2008; Pitti 2008). At its height in 1978, 30,000 strikers had suspended payment of their rent across 130 hostels (Hmed 2007). Despite its amplitude, however, the rent strike met with mixed success: a key demand of the strikers - for improved legal status as tenants, not residents - was never conceded by the authorities (Hmed 2007; Pitti 2008). ${ }^{8}$

Nonetheless, other important advances were secured, such as improved representation through the creation of residents' committees and the extension of the aide personnalisée au logement (APL), a social security housing benefit, to those living in hostels. Indeed, this latter measure has had the important long-term consequence of residentially fixing in the hostels a significant cohort of migrant workers whose economic prospects suffered in the 1980s, due to industrial crisis and unemployment. In effect the hostels became the only accommodation which these men could afford, since their incomes were not sufficient to accede to more spacious social housing and reunify their families (Bernardot 2008). Fast forward 20 or 30 years and it is this same cohort which now corresponds in large part to the population of over-60s found in the hostels. The consequence, as encapsulated in this book's title, is that the hostels have become in many cases de facto immigrant-only 'retirement homes'. Against a contemporary public discourse which frequently portrays the older hostel residents as passive victims of social and territorial exclusion in France, it is therefore important to acknowledge the legacy of the rent strike: not only as the precursor of the ageing clientele which now populates the hostels, but also as a reminder that these elders have demonstrated a strong sense of agency and activism in the past.

Cosmetic Adaptations and Rebranding as Adoma (1992-2012) In the second half of the 1980s Sonacotra's management sought to reduce its dependence on diminishing public funds and to counter its negative 'migrants-only' public image. It did so by diversifying its housing offer to new and financially better-off clienteles such as students and professionals on secondment (Bernardot 2008). From 1992, unimpressed by the results of this deviation, the various state institutions which held large stakes in the company acted to bring Sonacotra back to its original vocation as an instrument of social housing policy firmly under the state's supervision. However, the company's reboot heralded a break with the past in one key respect, namely that it was no longer just migrants who were to be the target clientele of Sonacotra, but all those in a precarious situation facing difficulties in acceding to ordinary social housing - young workers on short-term contracts, single mothers, homeless families, recovering drug addicts, and so on (Lévy-Vroelant 2007; Ridez et al. 2001).

\footnotetext{
${ }^{8}$ Interestingly, the resolution of the strike at local levels was partly achieved by installing prayer rooms in hostels, as religion was viewed as a calming factor by the management. By the early 1990s, Sonacotra was the number one provider of Muslim places of worship in France, with more than 200 hostels disposing of a prayer room (Bernardot 2008).
} 
A key element of this more generalised fight against exclusion in housing was the transformation of the migrant worker hostels into a new and expanded social housing category, the résidence sociale. This new statutory mechanism was intended to impel structural renovations to the many hostels which had fallen into disrepair, as well as to encourage more pro-active involvement of local municipalities in the attribution of places in this type of accommodation. Nonetheless, the programme to renovate France's 700-odd foyers is far from completion and considerably behind schedule, with the initial five-year programme begun in 1997 having been extended twice, firstly in 2001 and then again for the period 2007-2013 (Union d'Economie Sociale pour le Logement 2007). As of 2012, only 320 of the 680 hostels originally identified in the 1997 programme had been transformed into résidences sociales (258 following renovations and 62 without undergoing renovation) (Bachelay 2013: 86).

Indeed, Bernardot argues that the supposed 'transformation' of the migrant worker hostels is in fact largely a cosmetic change designed to "modify the discourse on the population housed in the hostels" (Bernardot 2008: 265; author's translation). Arguably since the rent strike, the company and its stakeholders in government have sought to break the link in the public imagination between Sonacotra and state-sanctioned labour immigration, which has become an increasingly toxic topic in French politics, as the rise of the far-right Front National party attests. As one hostel company employee put it to me, "The people who are antiimmigration don't like us because we provide housing for immigrants; the people who are pro-immigration don't like us because they say we lock immigrants up." Outwardly reorienting itself to the new publics described above is one means of decoupling the company from this negative 'migrants-only' image. A second means, again purely cosmetic, was the rebranding exercise which management undertook in 2007, when Sonacotra became Adoma. In effect, with these sleights of hand, the company has undertaken a double decoupling, through its new corporate identity and its emphasis on a new clientele which in numerical terms is insignificant compared to the resident population of ageing former guestworkers. Henceforth in this book the company will be referred to as Sonacotra-Adoma. ${ }^{9}$

For Marc Bernardot (whose publications on Sonacotra-Adoma I consider to be the reference works), these cosmetic changes are consistent with the company's "unofficial mission of 'invisibilisation' for those migrants who are too 'conspicuous"" (Bernardot 2008: 263; author's translation). While other groups of migrants have been subject to 'invisibilisation' at different times, ${ }^{10}$ contemporary evidence indicates that the company's older foreign clientele is increasingly a target here. The negative press coverage on ageing in the hostels which was cited in Chap. 1, beginning in the late 1990s, has prompted Sonacotra-Adoma to effectively 'air-brush' older residents from all outward-facing communications and marketing. The com-

\footnotetext{
${ }^{9}$ In a similar move, Aftam, the second largest hostel company, changed its name in 2012 to Coallia. Henceforth in the book it is referred to as Aftam-Coallia.

${ }^{10}$ See Bernardot (2008: 262-263) for a discussion of 'invisibilisation' in the context of Malian families who were rehoused by Sonacotra-Adoma in 1990.
} 
pany's 2015 Annual Report is instructive in this regard: of the 24 images of people featured in this 20-page document, just one is identifiable as an ageing resident (Adoma 2016). Yet residents over 60 make up around half the clientele in the foyers and résidences sociales and they arguably constitute a disproportionate outlay of resources for Sonacotra-Adoma given their age and state of health. Nonetheless, much more visible in this document are the "new missions" (ibid: 4-5) and "new face" (ibid: 8-9) of the company: young adults, both male and female, at the threshold of independence thanks to the dedicated support of the company's staff, who are pictured explaining administrative tasks. Also prominent are shots of children in family settings, alluding to the company's significant diversification into housing for asylum-seeking families since the early 2000s. ${ }^{11}$

In concluding this section, I wish to argue that Bernardot's contemporary insight about 'invisibilising' conspicuous foreigners also applies to the previous two 'ages' discussed above. In the initial phase - the Sonacotral era - the mission bestowed upon the company by its stakeholders in government was of critical importance given the Algerian war: to efface the insanitary shanty towns at the fringes of France's great cities, and to rehouse the most suspect elements of this population (i.e. single young Algerian men) in segregated accommodation far from the eyes of the native French. Similarly, during the second age of the hostels, when the priority of governmental stakeholders had shifted to maximising the potential for economic growth, Sonacotra became a tool by which France benefited from cheap flexible foreign labour without having to pay the indirect costs associated with it, namely the housing, schooling and healthcare costs attributable to their dependent family members. Thus the hostels served to 'invisibilise' the migrant workers' wives and children, by incentivising them to remain in the countries of origin.

Amongst a significant cohort of residents, this labour market-cum-border control strategy has been particularly effective, with the result that these men have lived apart from their families for the duration of their working lives. At retirement, as was intimated in Chap. 1, they tend not to return definitively to their families in places of origin, but instead prefer to constantly circulate back-and-forth between their hostels in France and their families in North and West Africa. As noted, much of the literature on the hostels has concentrated - and rightly so - on the alarming situation facing older residents in terms of ill-health, isolation and poverty. What has been far less evident is any attempt to develop explanatory or theoretical approaches. Indeed, this lack of engagement with theory is a wider feature of literature at the intersection of ageing and migration, as Sandra Torres and Ute Karl argue (Torres and Karl 2016). Yet I would argue that the hostels are rather fertile ground for generating new insights in migration theory. On the basis of both family localisation theory and neo-classical economics, one would expect the retired hostel residents to be the most likely candidates for return. That the men do not return definitively calls these theories into question.

\footnotetext{
${ }^{11}$ In 2015, Sonacotra-Adoma disposed of more than 13,000 places in its 169 reception centres for asylum-seekers, constituting a quarter of France's reception capacity and making SonacotraAdoma the number one operator of such accommodation (Adoma 2016).
} 
What then can account for the paradox? In the next section I proceed to identify four bodies of theory which could potentially be of use in accounting for the puzzle of the men's preference for the va-et-vient over definitive return. These four explanatory frames are the new economics of labour migration (Stark 1991); structuralism (Cerase 1974; Gmelch 1980) ${ }^{12}$; transnationalism (Portes et al. 1999); and social systems theory (Bommes 2012; Boswell and Ciobanu 2009).

\subsection{Theories of Migration and Return}

In Chap. 1 I noted the importance of remittances for hostel residents and their families. Viewing migration as a strategy to insure against risks to household income, the 'new economics of labour migration' approach is far better able to explain the significance of remittances than the neo-classical approach with its assumption of utility-maximising individuals. A second factor is the ability to re-integrate and gain acceptance by the home community after a long absence: the structuralist literature is useful here. Improved (and cheaper) communications and transport is a further factor of note: a burgeoning literature on 'transnationalism' has emerged in the last 20 years grounded largely in these explanatory variables. Finally, I underlined the worrying situation facing many hostel residents in terms of ill-health and poverty, and the importance of accessing healthcare and social security benefits: social systems theory provides an innovative framework for theorising such factors.

For each of these four theoretical models, the relevant explanatory variables are identified below and then applied to return at retirement, before concluding with an assessment of overall strengths and weaknesses.

The New Economics of Labour Migration In Chap. 1, the neo-classical economics approach to return migration was acknowledged as the principle alternative to theories prioritising family localisation and group ties. The neo-classical approach is commendable for its theoretical neatness and predictive potential regarding who migrates and under what circumstances. Yet often these predictions do not match the empirical evidence, most notably when people's migration behaviour does not tally with favourable wage differentials or purchasing power considerations. A further criticism is that in the neo-classical approach, to migrate is only ever an individual decision, a perspective which isolates migrants from their social context. Neo-classical accounts also find it difficult to account for the widespread practice of remittance sending. These latter two points can be more fruitfully unpacked using the perspective known as the new economics of labour migration (NELM).

In contrast to the neo-classical focus on the utility-maximising individual, the NELM approach places remittances and the "utility-maximizing family" (Stark

\footnotetext{
${ }^{12}$ 'Structuralism' is not a term which Cerase or Gmelch themselves used. Instead, I have been guided in this choice of terminology by Cassarino (2004), who uses this term to categorise their contributions in his typology of return migration theories.
} 
1991: 208) at the centre of analysis. Oded Stark argues that migration must be viewed as a strategy for insuring against risk to household income, with the family, rather than the individual, as the decision-making unit. Stark's analysis is built on three premises which challenged the previously dominant neo-classical 'expected income' approach: namely that "there is more to labor migration" than (i) individual utility-maximising behaviour, or (ii) wage differentials, and furthermore (iii) migration is a response to imperfectly functioning credit and insurance markets (Stark 1991: 3-4). Summarising the new economics of labour migration, Stark writes:

The underlying idea is that for the household as a whole it may be a ... superior strategy to have members migrate elsewhere, either as a means of risk sharing or as an investment in access to higher earnings streams. Remittances may then be seen as a device for redistributing gains, with relative shares determined in an implicit arrangement struck between the migrant and the remaining family. The migrant adheres to the contractual arrangement so long as it in his or her interest to do so. This interest may be either altruistic or more selfseeking, such as concern for inheritance or the right to return home ultimately in dignity (Stark 1991: 236-7).

Regarding this last point on returning home, the NELM principle of household risk-sharing means that the returning migrant can count on reciprocal support from the household in the place of origin at the end of working life when income drops. Return is thus the logical final step of the migration project. Unlike in certain versions of neo-classical theory, where return is interpreted as the failure of the migration project (see Cassarino 2004 for discussion), in NELM return is the final phase of a successful migration project. ${ }^{13}$ "Rather than being a mistake, return migration represents the final stage of a pre-established plan" (Constant and Massey 2002: 11). Adopting the NELM approach, Amelie Constant and Douglas Massey (2002) show that remitting regularly and having a spouse in the home country are strongly correlated to retirement return. Likewise, for Russell King, remittances are "an expression of the commitment to the home area and an eventual desire to return" (King 1986: 23).

In summary, NELM significantly advances our understanding of the social context in which migration takes place, most notably in the realm of remittances as household insurance. The individualistic utility-maximising neo-classical approach tends to see remittances as irrational, and can only explain this phenomenon through recourse to the thorny concept of altruism. However, two criticisms have been levelled at NELM: firstly, that motivations to migrate and return are purely economic, with returnees perceived purely in terms of monetary value back home - as "foreignincome bearers" or "financial intermediaries" (Cassarino 2004: 257). Secondly, as with neo-classical approaches, the NELM perspective largely ignores the setting to which migrants return, with return being conditional on economic success or failure in host countries. Although NELM contends that the left behind household is a key

\footnotetext{
${ }^{13}$ While the question of whether return is the product of a successful or failed migration has been a key debate among scholars in the past (Cerase 1974; Gmelch 1980), I do not find this dichotomy particularly useful, since it reduces the issue to a blunt economic calculation, ignoring social and political factors. As King (1986) points out, what counts as success or failure is highly context-dependent.
} 
referent in return decision-making, NELM is silent on broader social structures in the place of origin. Neo-classical and NELM theories therefore underestimate the issue of re-integration in the 'home' community, an oversight which is addressed by the structuralist approach.

Structuralism In the structuralist perspective on return migration, the decision to return is not solely a utility-maximising calculation, be it at the individual level or household level. One must additionally take into account social, institutional, and contextual factors in the place to which migrants are planning to return. These factors are summarised by Francesco Cerase as "vested interests and traditional ways of thinking", and include political norms and institutions; economic structures (dominant sectors and modes of production, as well as the interests of the owners of the means of production); and finally the normative values structuring social relations in a given context (Cerase 1974: 258). The latter theme has been theorised by various scholars taking what has been labelled the 'cultural embeddedness' approach (for a discussion, see Boswell and Ciobanu 2009). Foremost among them are William Kandel and Douglas Massey (2002), who speak of a 'culture of migration' when cross-border mobility becomes so entrenched in a community's collective consciousness that it becomes normative. Among countless other phenomena associated with migration, such a culture is likely to generate norms concerning the decision to return. To give one example from Byron and Condon's work with retired Nevis Islanders in the UK, some find return difficult because it is "important to demonstrate material evidence of 'bettering oneself' (...) Return may (...) be prevented by the fear of appearing inadequate. After so many years away, migrants are expected to be wealthy" (Byron and Condon 1996: 99-100).

Structuralism is a perspective emerging from studies in sociology and anthropology, with Cerase's research on the return of Italians from the United States being a pioneering example. Cerase (1974) posited four motivations or types of return: returns of failure; returns of conservatism; returns of innovation; and returns of retirement. Regarding the latter, the 'detachment' of retired emigrants stems from the fact that the individuals in this category tend not to have raised a family in the host society and therefore have "no one to whom they can bequeath the results of their efforts and aspirations. Advancing age and other dissatisfactions in the new society may cause real suffering, which can be relieved only by a return home" (Cerase 1974: 251). In Cerase's reading, those in the retirement return category, since they reinforce rather than challenge local political and economic structures, find it relatively easy to re-adapt to life in the community of origin. Returnees nevertheless may have to re-adapt their behaviour to the normative expectations of the family and the home society. In Dumon's words, "the returnee can be defined as the person who, in order to be reaccepted, has to readapt to the changed cultural and behavioural patterns of his community of origin" (Dumon 1986:122). In an echo of Cerase's 'returns of innovation', Ken Sun describes the attempts of ageing Taiwanese returnees to contribute to Taiwan through their professional knowledge and networks gained while abroad. Nonethelesss, they face significant structural constraints in their attempts to do so (Sun 2016). 
While the structural perspective is invaluable in shedding light on the process of re-integration which is usually ignored in the neo-classical and NELM theories due to the prioritisation of host country economic outcomes, two criticisms can be levelled at the structuralist literature. First of all, such accounts can be critiqued for arguing that the process of return is mediated by structural conditions only in the home community, ignoring structural conditions in host countries. Secondly, the principal reason for the difficulties encountered following return in structuralist accounts is that homeland contextual and structural factors can only be fully evaluated once returned migrants have re-installed themselves. They are thus "ill-prepared" for their return, as they have based their decision on "incomplete information" (Gmelch 1980:143). The implication is that migrants do not have reliable information from home because they find it difficult to maintain contact with their places of origin. This latter point is challenged most directly by those working from a transnationalist perspective.

Transnationalism The term 'transnationalism' as it refers to migration describes ties that migrants in host states maintain with their homelands and with co-ethnics/ co-nationals in other locations outside the homeland. Such ties can be material or symbolic, and can take economic, political or socio-cultural forms. The transnationalism literature sets out a range of necessary empirical conditions for the emergence and importantly the retention over time of cross-border ties. These conditions include ease of mobility and ease of communications, as well as the social and political contexts of sending and receiving countries (Faist 2004; Itzigsohn 2000; Kivisto 2001; Portes et al. 1999). While transnationalism is generally deployed to describe migrants' ties with people and places back home rather than migratory movement per se, clearly such movement is a necessary pre-condition for these ties: "It is the ability to return and reemigrate - to circulate, in other words - that underpins transnationalism" (Black and King 2004: 80).

Thus, the ability to circulate becomes a valuable and coveted resource for transnational actors. Regular participation in transnational activities such as home visits, remittance sending, and keeping abreast of economic and political developments in the place of origin means that emigrants are better prepared for return. An important potential resource is the ability to exploit information and communication technologies (ICTs), which can facilitate the exchange of information from home. While generally such communicative tools are depicted as the preserve of younger, technologically-savvy generations, there is some evidence that ICTs are also "manifestly changing older people's lives, not least those of relatively low income and from ethnic and cultural minorities" (Warnes 2009: 359-60).

The most obvious contribution of the transnational literature regarding return is that it is able to move beyond narrow formulations that restrict the decision to a binary choice between definitive settlement and definitive return. Rather, the transnational approach shows that return no longer needs to be viewed as the end of the migration project. Such an approach is much better able to comprehend the backand-forth mobility of the hostel residents.

Transnationalism is not without its critics however (Sheffer 2006; Waldinger \& Fitzgerald 2004). Pertinent to the question guiding this book, one critique concerns the determinism that transnational accounts attribute to inherited membership in 
ethnic and kinship groups, with relationships between migrants and non-migrant kin being "written in stone" rather than being dynamic over time (Lacroix 2013: 1021; see also Sinatti and Horst 2015). As Cassarino (2004: 265) notes: "[T]he transnational approach to return migration seems to encapsulate [migrants'] initiatives and projects at home in a fundamental set of mutual obligations, opportunities and expectations stemming from common ethnicity (i.e., the diaspora) and kinship (i.e., the family, the household)." Relying on mutual kin obligations in this way, the transnationalism literature cannot explain why some people are heavily invested in cross-border activities while other compatriots are not. In summary, the transnational approach has value in explaining how people maintain cross-border social ties (transport, communications technology), but it cannot fully explain why they do so.

Social Systems By contrast, an emerging approach in migration and integration studies ${ }^{14}$ employs a theory of society in which there is no longer a place for preascribed membership in kinship and ethnic groups. Instead of society being constituted by large collectivities of individuals - be that in kin groups, tribes, ethnic groups or nations - Niklas Luhmann proposed an alternative theory whereby society is constituted by individuals' communication in different social realms such as the economy, law, politics, religion, the family, education, and healthcare (Luhmann 1995). Access to such systems operates according to fundamentally inclusive criteria.

In his theory of social systems, Luhmann locates a fundamental break between pre-modern and modern societies beginning in Europe during the course of the eighteenth century. Up until this time, society had been structured on the basis of group membership - either in 'segmented' clans or tribes, or in hierarchically 'stratified' classes or ranks (Luhmann 1977). With the fundamentally egalitarian restructuring of society unleashed by the French Revolution, membership in groups on the basis of ascribed or inherited characteristics became less and less important. Arguably, even membership in the nation-state has in recent decades lost some of those qualities which led Rogers Brubaker to describe citizenship as the 'master status' (Brubaker 1994; Soysal 1994). The organisations of society - with the exception of the national welfare state in the political system - are increasingly unconcerned by demarcations of territory and national belonging (Bommes and Geddes 2000; Halfmann 2000). This is seen for example in the emergence of a global financial system, a corpus of international law, cross-border scientific cooperation, 'health tourism', and supra-national political institutions.

At first glance the foregoing may seem somewhat opaque, but Luhmann's theory of functional differentiation is in fact extremely pertinent both to the question under consideration here, and to migration studies more broadly, for two reasons. Firstly, the theory provides a radical new framework for viewing migration by proposing that international mobility should not be understood as an exceptional act (Goldin et al. 2011), but rather as a perfectly expectable response to the inclusive and deterritorialised functioning of all social systems barring the political system. As Boswell

\footnotetext{
${ }^{14}$ See for example Bommes 2000, 2012; Boswell and Ciobanu 2009; Halfmann 2000.
} 
and D'Amato note, “the systems most important to an individual's well-being tend to be blind to their national or ethnic origin" (Boswell and D'Amato 2012: 12). Secondly, the far-reaching implications of systems theoretic thinking become clear when one revisits the earlier discussion about integration and 'implantation' in the reference groups of family, class, and nation. If society is no longer structured along these lines, to theorise immigrant integration in this way is problematic (Bommes 2012). Rather than integrating into such groups, a social systems response to the question 'integration to what?' replies that immigrants integrate into social systems, or rather the organisations of the various relevant systems.

In principle, access to these communicative systems is open to every social agent, because the differentiation of society into functions (such as politics and law) rather than social strata (such as ranks or castes) no longer permits discrimination on the basis of inherited or ascribed characteristics. In practice, inclusion in function systems cannot be assumed but instead is processed through organisations such as courts, hospitals, firms, schools, and so on, which can only discriminate on the basis of whether function-specific "rules of access" are satisfied or not (Luhmann 1990: 35). The effect of such rules is to ask, for example, whether a candidate for a job has a certain qualification, whether one is ill or not, or whether one's legal status is recognised under such and such a jurisdiction. In principle, therefore, modern society is much more inclusive and neutral than its pre-modern precursors. Nonetheless, in practice the likelihood of failing to achieve inclusion in a given system can sometimes be quite high (e.g., unemployment). Thus the organisations of the welfare state in the political system have evolved in the last century or so to mediate the exclusionary tendencies of modern society and to equip citizens with the characteristics required to fulfil social participation, via social programmes in education, health, labour markets, and so on.

This is not to say that the effects of welfare state institutions are not discriminatory in their outcomes. Indeed, these outcomes may appear discriminatory precisely on the basis of inherited attributes such as race, religion, or other axes of prejudice, as the position of immigrants amongst the most disadvantaged groups in many European countries would indicate (in terms of income, educational attainment, access to housing and so forth). However, Michael Bommes argues that these outcomes are not primarily grounded in nativist preferences but instead are a consequence of migrants diverging from the 'standard' assumed lifecourse institutionalised by the welfare state. Welfare state programmes "accompany individuals from early childhood onwards, through to pension age and death" (Bommes 2008: 144). Given that most people tend not to emigrate until adulthood and thereby miss out on the biographical structuring institutionalised by the welfare state in the formative years (healthcare, education, contributions to social security and pension funds), they face higher "risk of exclusion [e.g., from the labour market] and reduced access to welfare provision" (Bommes 2008: 148). In such a conception of society, it is one's "biographically accumulated" markers of inclusion which are important (Bommes 2000: 91), not inherited attributes. Hence the new significance in this day and age for proofs of identity and life history such as passports, identity cards, CVs, medical records, national insurance numbers, and social security files. 
For migrants at retirement, Luhmann's theory of functional differentiation is important insofar as an individual's requirements for achieving social inclusion have a bearing on the decision to settle or return at retirement. In this, a lifecourse perspective is imperative since the relevant systems change during the lifecourse. The critical juncture of retirement means that migration is no longer predicated on employment (i.e., inclusion in economic organisations). What becomes much more important at this stage in the life course is inclusion in the organisations of the healthcare and welfare systems, in order to access goods such as pensioners' allowances and medical treatment. These points will be expanded in Chaps. 3 and 4 respectively. Before then, however, a brief discussion of research methods is warranted.

\subsection{Methods at the Margins}

In terms of research methods, the above review of theories indicated a direction of travel at the outset of this study. Specifically it indicated that neo-classical economics and family localisation theories do not have purchase on the question of the hostel residents' puzzling late-in-life mobility. It was therefore clear to me that to obtain a satisfactory answer would require something other than a quantitative analysis of income differentials, purchasing power, or family structure and location data. Rather, the complexity and sensitivity of the alternative explanatory factors outlined above - family remittance strategies, norms underpinning social relations in the places migrants return to, changing practices of long-distance communication, or healthcare needs, to name only some of the most prominent - suggested that a more qualitative approach was in order. In my research with hostel residents, biographical methods and ethnography became privileged sources of data. When seeking information from the organisations which are called upon to intervene in hostels, such as care providers, social security agencies and NGOs, semi-structured interviewing techniques were more fruitful. To conclude this chapter I now present the design of the study and the rationale for combining these different methods.

The Lived Life and the Told Story Biographical research encompasses a broad range of methods and materials which in one way or another make individual lives legible, literally 'life writing'. These include oral histories, diaries, letters, photographs and autobiographical narratives (Denzin 1989). At its core is "the collection and interpretation of 'personal' or 'human' documents" (Roberts 2002: 1). The popularity of biographical research has risen in recent decades, to the point of constituting a 'biographical turn' (Chamberlayne et al. 2000). This reflects both a disenchantment with positivist quantitative social science and a normative injunction to give voice to people's experiences, especially those who have been "hidden from history", or "spoken for" by others (Wengraf 2000: 140). In addition to these normative and epistemological considerations, a biographical approach is particularly suited to the terrain of inquiry studied here. 
In this book, retirement is perceived as a significant juncture or turning point in the lifecourse. Indeed for some of my respondents it was experienced negatively as an unsettling rupture heralding loss and decline. Biographical methods, as Brian Roberts writes, are useful in such contexts by "reveal[ing] how ageing is experienced and how individuals 'theorize' about the changes in their lives as they 'age"" (Roberts 2002: 28). Migration, too, may entail significant ruptures and discontinuities and biographical methods can likewise enable researchers to access and interpret them (Apitzsch and Inowlocki 2000; Breckner 2002; Schutz 1971). Indeed it is in migration studies that biographical methods were first pioneered and gained prominence (Fischer-Rosenthal 2000: 119), in particular via the seminal contribution of Thomas and Znaniecki (1918) in The Polish Peasant in Europe and America. With explicit reference to late-in-life return migration, Warnes and Williams (2006: 1273) note the contributions which a lifecourse focus can make to understanding "not only (...) one or more linked migration events, but also the antecedents and long-term consequences in their temporal, geographical and socio-political contexts." In his work about displaced people in Bosnia-Herzegovina, Stef Jansen shows how people's perspectives on return differed according to the stage of life they had reached (Jansen 2007).

Given the above, a biographical lifecourse-centred approach appeared to hold significant promise in terms of accessing nuanced perspectives from hostel residents on their preference for late-in-life mobility over definitive return. This initial hunch was confirmed in my piloting work, during which I came to realise the importance for hostel residents of healthcare and welfare entitlements in France. This led me to accord particular importance to the explanatory potential of Luhmann's social systems theory, as presented in the previous section. In this paradigm, as noted, societal inclusion is strongly predicated upon the career or 'biography' which the individual can offer as proof of meeting the expectations of various organisations in society (Luhmann 1990). In such a conception of society, it is one's "biographically accumulated" markers of inclusion which are important: in other words, an observable record of the individual's past development over time (Bommes 2000: 91).

My reading led me to experiment with the Biographical Narrative Interview Method, developed by Tom Wengraf. The observable record of an individual's past corresponds to the 'lived life' (Wengraf 2000) or 'life history' (Fischer-Rosenthal 2000), namely 'harder' and more verifiable facts. The lived life is not necessarily (only) self-narrated but may instead (or in addition) be comprised of documents from various organisations and institutions (Wengraf 2000), for example certificates of education and training, payslips, identity cards and so on. Thus, a person's life history forms the backdrop to the other central element of biographical narration, the life story interview (Fischer-Rosenthal 2000) or what Wengraf (2000) calls the 'told story'. This is an open invitation to the participant to 'tell your own story, in your own way' (Wengraf 2000). The result is a self-reflective and interpretive narrative, aiming to present a convincing account of "how we became who we are" so as to appear "both consistent and contingent. Even if I have gone through many 
contradictory phases in my life, the story I can tell presents me as myself"' (FischerRosenthal 2000: 115, emphasis in original).

My first months visiting hostels were spent in the company of Abdou, from a migrant rights association which provided weekly drop-in administrative advice sessions in several Sonacotra-Adoma hostels in the northern Parisian suburbs. It was during this piloting phase that I first realised the importance of healthcare and welfare entitlements in timetabling the older hostel residents' transnational mobility, as will be elaborated in Chaps. 3 and 4 . I mention this point now however in order to introduce a second important distinction: that between individual biographies (i.e., a person's life history and life story) and what I will call organisational biographies. The latter are the timeframes, deadlines and eligibility conditions which organisations impose on individuals in society. As Fischer-Rosenthal proposes:

[Biography] is a structure operating in both spheres. (...) Biography is the social structure provided by society, as it institutionalises and organises the many types of timetables one has to go through in a lifetime and it is the individual story always in the process of being told, which he or she can and must tell (Fischer-Rosenthal 2000: 118; emphasis in original).

In order to access these organisational biographies, I analysed a large number of texts, such as social security laws, administrative regulations, court judgements, documentation from hostel companies and care providers, and legal guidance produced by migrant rights associations. During the main period of fieldwork (20082009), approximately 50 semi-structured interviews - with representatives from bodies including care providers, embassies and consulates, various government agencies, migrant rights NGOs, politicians, and hostel companies - gave insights into how organisational timetables were implemented in practice. A further round of interviews was conducted in early 2016 following the entry into force of the Aid for Familial and Social Reinsertion (see Sect 8.3). By elucidating individual stories in their institutional context, I hoped to be better able to understand broader social changes and illuminate what Russell King calls:

the double embeddedness of migration; at the individual scale, migration must be embedded in a migrant's life course (and in some cases of the lifecourse of the family, even across generations); and at the macro scale, the study of migration must be embedded in the societies and social processes of the both the countries/places of origin and of destination (King 2002: 101).

Ethnography, an Act of Submission to a Total Institution Doing good biographical research is an exacting craft. This piece of research was my apprenticeship, and suffice it to say that my early attempts were a failure. This was at the time I was accompanying Abdou at his drop-in advice sessions. On these visits I chatted informally with residents waiting to see Abdou and piloted a technique known as the 'life grid' (Parry et al. 1999). ${ }^{15}$ My aim with this method was to place the important

\footnotetext{
${ }^{15}$ Essentially, one starts with a grid, with one chronological axis, and the other axis listing the various relevant life domains - family, work, leisure, housing, health, and so on. Where there is uncer-
} 
events in respondents' lives - connected to work, family, health, migration etc. - in a chronological order. In addition to the important details of life history which I hoped it would reveal, the life grid was a means of building rapport with individuals, since it required an element of team-working to reconstruct respondents' timelines.

My hope was that doing life grids would lead naturally enough to longer life story interviews with respondents, but my invitations to "talk about their life in migration" were always met with polite refusal. In my fieldnotes I recorded that respondents "felt this [request] was too vast, not specific enough. They're not going to want to be that open so early on" (Fieldnotes 17 May 2009). In time I began to realise that these refusals to be formally interviewed were in themselves revealing of the wider dilemma the hostel residents faced at retirement, and for that reason I have included some of this rich testimony in the Appendix for those readers who are interested.

Understanding this reticence to participate was also sometimes a question of interpreting silences and pauses, to read between the lines of my conversations with residents. Although return migration does not appear at first view to be a particularly sensitive topic, this is to forget that the vow to return 'one day' - and at the latest by retirement - was a collective promise made to thousands of wives and children 'left behind' in places of origin. Such expectations of return were also part of collective consciousness in the home and host societies, among policymakers and the general public alike.

Furthermore, as a corollary of the socio-spatial marginalisation blighting the hostels, I encountered deep suspicion among residents towards the AdomaSonacotra company, and its supervisory stakeholders in the French state. Such suspicion logically extended to research projects facilitated by the company, such as my own. The hostel residents' attitudes, bordering on a siege mentality, suggested to me that the accommodation itself had an institutionalising effect on those living there. Indeed research on migrant hostels in both France (Ginesy-Galano 1984; Hmed 2006; Sayad 2006) and South Africa (Ramphele 1993) has made a strong case that such forms of accommodation represent a type of 'totalising institution' (Goffman 1968). I began to realise that in order to understand and break down the above barriers to participation, I would need to submit myself in some way to these institutional forces. In short, I realised that I would need to move into a hostel and reside there for an extended period of time. This led me to spend 3 months living in a hostel in a north-western suburb of Paris. Figures 1.2, 1.3, 1.4, 1.5, 1.6, 1.7, 1.8, 1.9 and 1.10 provide a photographic glimpse of life there.

Ethnographic participant observation is a privileged method to study the effects of such institutionalisation when working with 'marginal' groups. Indeed, some would argue that ethnography may be more or less obliged when "poverty, lack of infrastructure, illiteracy, or political violence impede [other forms of] research"

tainty over a sequence of events in one domain, cross-referencing with an event in another domain, for example the birth of a son or daughter, can aid memory for distant events. It is also a flexible tool, allowing respondents to switch to different domains, start, stop or continue at different places, and cross-reference events in different domains (Parry et al. 1999). 
(Schatz 2009: 304). Initially then, there was an element of compulsion in my choice to engage in ethnography, following the futility of my efforts at life story interviewing during the pilot stage. However, with time and - more importantly - practice (of ethnography), I came to agree entirely with Erving Goffman's approach to studying institutionalisation, when he writes -.

It $[\ldots]$ is my belief that any group of persons develop a life of their own that becomes meaningful, reasonable, and normal once you get close to it, and that a good way to learn about any of these worlds is to submit oneself in the company of the members to the daily round of petty contingencies to which they are subject (Goffman 1968: 7).

As noted, the majority of hostel residents are North African and approximately one third hail from Francophone West Africa. Hostels housing predominantly North African populations are found in great number throughout France, but West Africans have tended to congregate in hostels in the Paris region (Bernardot 2006). To include both North and West African respondents in the study, it therefore made practical sense to restrict the terrain of research to Paris and the suburban départements which surround it. Furthermore, given the multi-sited character of hostel residents' lives at retirement, 'getting close' to them necessarily entailed ethnographic fieldwork in their places of origin (see also Rodríguez and Egea 2006). ${ }^{16}$ In this, I was fortunate and honoured to accompany a few of my respondents on their visits home. This gave me precious insights into family life as a guest in the family home. But my efforts in 'following the people', as ethnographer George Marcus (1998) enjoins, did not mean my multi-sited study was confined to two locations, i.e. France and the place of origin. Rather, I was conscious that the times and spaces of transit between home and host countries could be privileged observation points: to study 'travelling cultures' requires travelling researchers (Clifford 1992). These voyages brought home to me the gruelling embodied nature of the hostel residents' trips, with my journeys to both Tiznit in southern Morocco and Dembancané on the Senegal/ Mauritania border lasting several days in each direction. Figures 2.4, 2.5, 2.6, and 2.7 capture moments from these journeys, by various combinations of bus, boat and plane.

In summary, ethnography became a useful (indeed essential) precursory tool to generate the trust and rapport necessary before the more emotionally involved act of life story interviewing could be undertaken. It is doubtful whether I would have been able to generate the necessary trust and rapport to answer my theoreticallydriven questions well if I had employed a more conventional methodology such as semi-structured interviewing. By doing rich, descriptive ethnographic groundwork I was able to get to know my fellow hostel residents well and, in time, to be party to the knowledge required to understand the puzzle/dilemma of the preference for the va-et-vient over definitive return. In so doing I was also able to generate a much

\footnotetext{
${ }^{16}$ It is noteworthy that, barring a study by Jacques Barou (2001), research about hostel residents has been focused exclusively in France, ignoring the home context which is self-evidently important to many residents, and where some spend the larger portion of their time.
} 


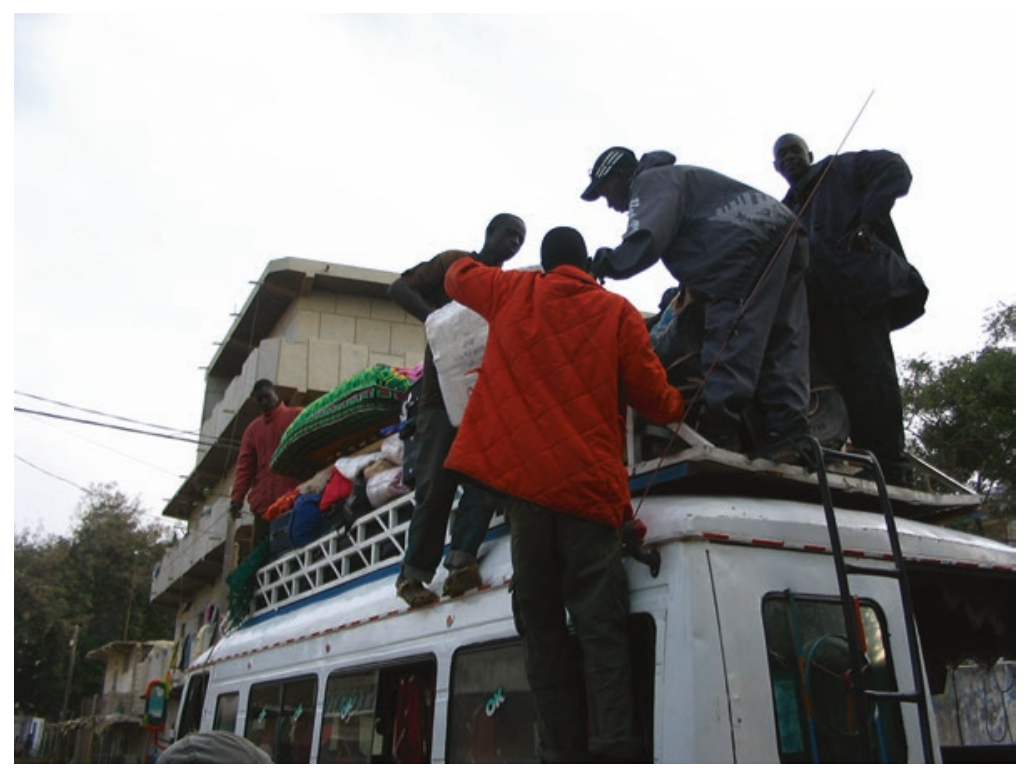

Fig. 2.4 In Dakar, preparing for departure to Dembancané

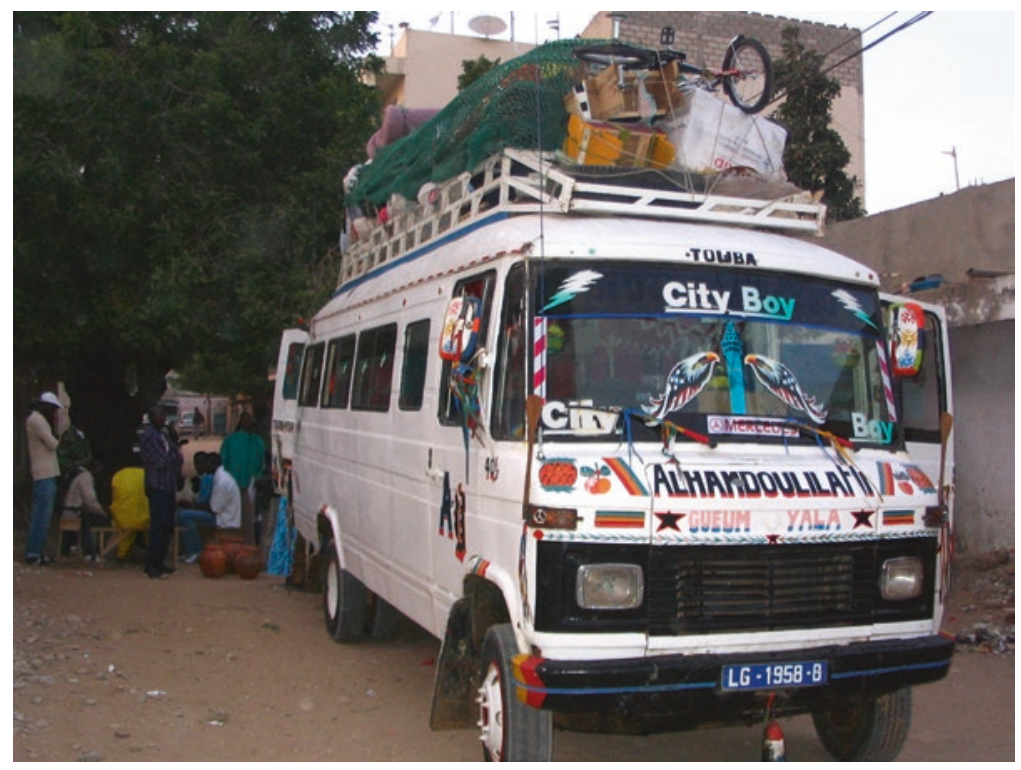

Fig. 2.5 A bus weighed down by family expectations 
Fig. 2.6 Motorway sign (Andalusia, Spain): the Arabic script at the top says 'rest stop'

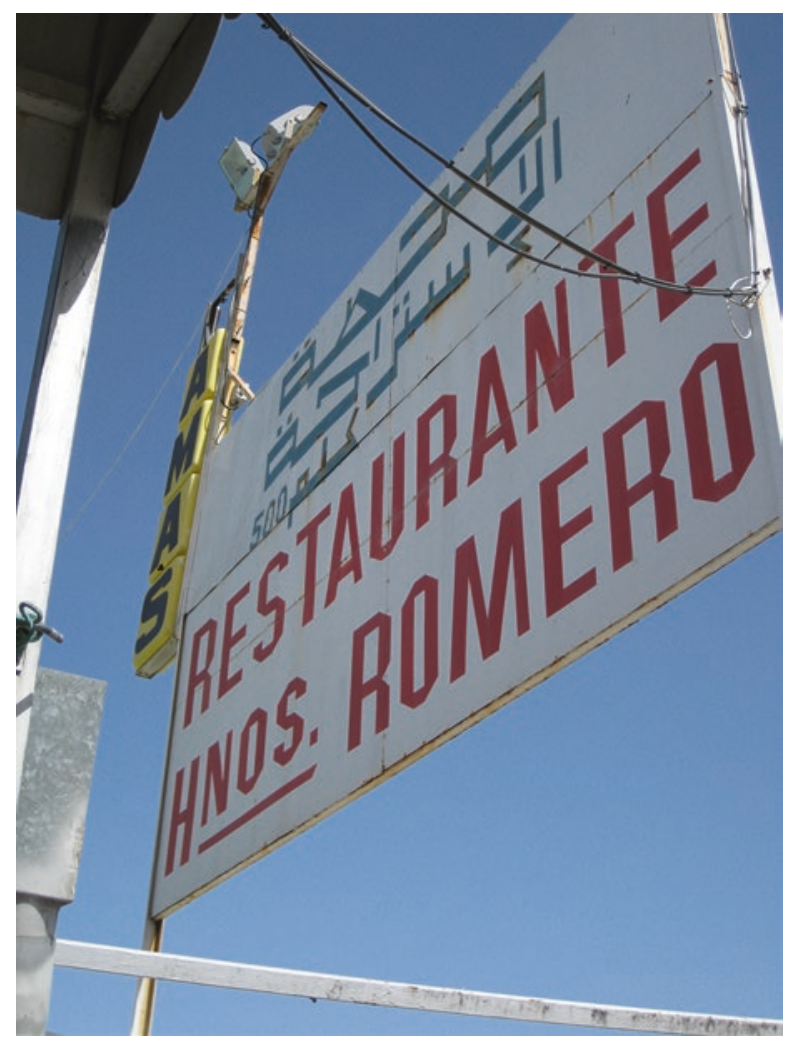

richer picture of their lives and, I hope, a more convincing account. I leave it for readers to judge. ${ }^{17}$

The pilot work was not only instructive in steering the ethnographic disposition of the study. As noted, it also revealed the importance of healthcare and social welfare entitlements in decisions about residence and mobility. Time and again, I was struck by the fact that hostel residents felt compelled to justify their presence in France. This justification was offered without my prompting it, and often within a few minutes of meeting. Almost invariably, hostel residents would justify their presence in France on the basis of healthcare needs or administrative paperwork. Healthcare of course becomes more important as one ages, and indeed for some of my respondents the body itself constituted a biographical marker of the hard working lives they had endured, as did their medical records and case notes. These biographical forms are discussed in Chaps. 4 and 7. Likewise, administrative records such as passports, tax files and social security dossiers are all biographical artefacts which have a bearing on hostel residents' late-in-life mobility, as I discuss next in Chap. 3.

\footnotetext{
${ }^{17}$ For those who are interested to know more about how the research design was implemented in practice, details are to be found in the Appendix.
} 
Fig. 2.7 The Paris-Tiznit coach, at the Port of Algeciras, Spain

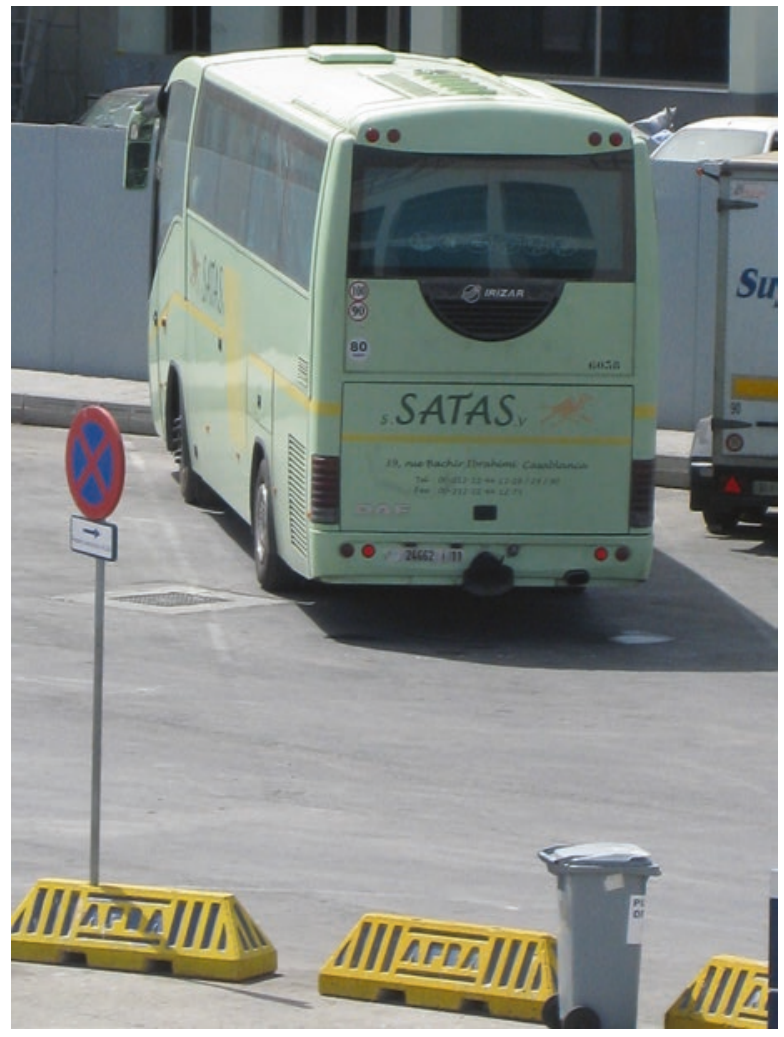

\section{References}

Adams, A. (1977). Le Long voyage des gens du fleuve. Paris: F. Maspero.

Adoma. (2016). Rapport annuel 2015. Paris: Adoma. http://www.adoma.fr/userdata/c_bloc_ file/0/691/691_fichier_Adoma-RA-BD.pdf

Amin, S. (1974). Introduction. In S. Amin (Ed.), Modern migrations in Western Africa (pp. 3-126). London: Oxford University Press.

Apitzsch, U., \& Inowlocki, L. (2000). Biographical analysis: A 'German' school? In P. Chamberlayne, J. Bornat, \& T. Wengraf (Eds.), The turn to biographical methods in social science: Comparative issues and examples (pp. 53-70). London: Routledge.

Atouf, E. (2002). Les conditions d'existence des populations 'nord-africaines' dans l'immigration à travers l'état des lieux du logement et de la santé, 1942-1965. Migrations et Santé, (n $\left.{ }^{\circ} 113\right)$, 59-86.

Bachelay, A. (2013). Rapport d'information fait au nom de la mission d'information sur les immigrés âgés (No. 1214). Paris: Assemblée nationale.

Barou, J. (2001). Etre père à distance: le devenir des enfants demeurés au pays d'origine. Paris: Sonacotra/UNICEF. 
Bathily, A. (1972). La conquête française du Haut-Fleuve (Sénégal) 1818-1887. Bulletin de l'Institut Fondamental d'Afrique Noire, Série B: Sciences Humaines, 34(1), 67-112.

Ben Jelloun, T. (1977). La plus haute des solitudes: misère affective et sexuelle d'émigrés nordafricains. Paris: Éditions du Seuil.

Bernardot, M. (1997). Une politique du logement : la Sonacotra (1956-1992). Unpublished doctoral thesis. Université de Paris 1 - Panthéon Sorbonne, Paris.

Bernardot, M. (1999). La Sonacotra: 40 ans de politique de logement social. Migrations Société, 11(63), 25-40.

Bernardot, M. (2001). Le vieux, le fou et l'Autre, qui habite encore dans les foyers ? Revue Européenne de Migrations Internationales, 17(1), 151-164. http://doi.org/10.3406/ remi.2001.1766.

Bernardot, M. (2006). Les foyers de travailleurs migrants à Paris : voyage dans la chambre noire. Hommes \& Migrations, 1264, 57-67.

Bernardot, M. (2008). Loger les immigrés: La Sonacotra 1956-2006. Broissieux: Editions du Croquant.

Black, R., \& King, R. (2004). Editorial introduction: Migration, return and development in West Africa. Population, Space and Place, 10(2), 75-83. http://doi.org/10.1002/psp.318.

Boissonnat, J. (1958, April 15). Entretien avec le président de Baticop Logéco. La Croix.

Bommes, M. (2000). National Welfare State, biography and migration: Labour migrants, ethnic Germans and the re-ascription of welfare state membership. In M. Bommes \& A. Geddes (Eds.), Immigration and welfare: Challenging the borders of the welfare state (pp. 90-108). London: Routledge.

Bommes, M. (2008). Welfare systems and migrant minorities: The cultural dimension of social policies and its discriminatory potential. In G. Farrell \& F. Oliveri (Eds.), Reconciling migrants' well-being and the common interest - Economy, welfare state and citizenship in transition (pp. 129-158). Strasbourg: Council of Europe.

Bommes, M. (2012). Transnationalism or assimilation? In C. Boswell \& G. D'Amato (Eds.), Immigration and social systems: Collected essays of Michael Bommes (pp. 107-124). Amsterdam: University of Amsterdam Press.

Bommes, M., \& Geddes. (2000). Introduction: Immigration and the welfare state. In M. Bommes \& A. Geddes (Eds.), Immigration and welfare: Challenging the borders of the welfare state (pp. 1-12). London: Routledge.

Boswell, C., \& Ciobanu, O. (2009). Culture, utility or social systems? Explaining the crossnational ties of emigrants from Borşa, Romania. Ethnic and Racial Studies, 32(8), 1346-1364. http://doi.org/10.1080/01419870802245026.

Boswell, C., \& D'Amato, G. (2012). Introduction. In C. Boswell \& G. D'Amato (Eds.), Immigration and social systems: Collected essays of Michael Bommes. Amsterdam: Amsterdam University Press.

Boutaleb, B. (2000). Vieillir en foyer: les immigrés algériens retraités dans les foyers de la région parisienne. In C. Lévy-Vroelant (Ed.), Logements de passage: Formes, normes, expériences (pp. 145-173). Paris: Editions L'Harmattan.

Breckner, R. (2002). 'Migrants': A target-category for social policy? Experiences of firstgeneration migration. In P. Chamberlayne, M. Rustin, \& T. Wengraf (Eds.), Biography and social exclusion in Europe: Experiences and life journeys (pp. 213-228). Bristol: Policy Press.

Brubaker, R. (1994). Citizenship and nationhood in France and Germany (2nd printing). Cambridge MA; Harvard University Press.

Byron, M., \& Condon, S. (1996). A comparative study of Caribbean return migration from Britain and France: Towards a context-dependent explanation. Transactions of the Institute of British Geographers, 21(1), 91-104. http://doi.org/10.2307/622927.

Cassarino, J.-P. (2004). Theorising return migration: The conceptual approach to return migrants revisited. International Journal of Multicultural Societies, 6(2), 253-279.

Castles, S., Booth, H., \& Wallace, T. (1984). Here for good: Western Europe's new ethnic minorities. London: Pluto Press. 
Cerase, F. P. (1974). Expectations and reality: A case study of return migration from the United States to southern Italy. International Migration Review, 8(2), 245-262.

Chamberlayne, P., Bornat, J., \& Wengraf, T. (2000). Introduction. In P. Chamberlayne, J. Bornat, $\&$ T. Wengraf (Eds.), The turn to biographical methods in social science: Comparative issues and examples. London: Routledge.

Clifford, J. (1992). Travelling cultures. In L. Grossberg, C. Nelson, \& P. A. Treichler (Eds.), Cultural studies (pp. 96-116). New York: Routledge.

Conseil économique. (1956). Titre IV Cas spéciaux: Chapitre 2, L’hébergement des salariés nordafricains occupés en métropole. In Séances des 24 et 25 janvier 1956: Logement des travailleurs de faibles revenus. Paris: Direction des journaux officiels.

Constant, A., \& Massey, D. S. (2002). Return migration by German Guestworkers: Neoclassical versus new economic theories. International Migration, 40(4), 5-38. http://doi. org/10.1111/1468-2435.00204.

De Haas, H. (2007). Morocco's migration experience: A transitional perspective. International Migration, 45(4), 39-70. https://doi.org/10.1111/j.1468-2435.2007.00419.x.

Denzin, N. K. (1989). Interpretive biography. Newbury Park: Sage.

Dumon, W. (1986). Problems faced by migrants and their family members, particularly second generation migrants, in returning to and reintegrating into their countries of origin. International Migration, 24(1), 113-128. http://doi.org/10.1111/j.1468-2435.1986.tb00105.x.

Faist, T. (2004). The border-crossing expansion of social space: Concepts, questions and topics. In E. Özveren \& T. Faist (Eds.), Transnational social spaces: Agents, networks, and institutions (pp. 1-34). Aldershot: Ashgate.

Fischer-Rosenthal, W. (2000). Biographical work and biographical structuring in present-day societies. In P. Chamberlayne, J. Bornat, \& T. Wengraf (Eds.), The turn to biographical methods in social science: Comparative issues and examples (pp. 109-125). London: Routledge.

Gallou, R., \& Rozenkier, A. (2006). Le vieillissement des hommes immigrés isolés en foyer. In La vieillesse des immigrés, isolés ou inactifs en France (pp. 9-117). Paris: La Documentation Française.

Ginesy-Galano, M. (1984). Les Immigrés hors la cité : le système d'encadrement dans les foyers: 1973-1982. Paris: Éditions l'Harmattan / CIEM.

Gmelch, G. (1980). Return migration. Annual Review of Anthropology, 9, 135-159.

Goffman, E. (1968). Asylums: Essays on the social situation of mental patients and other inmates. London: Penguin Books.

Goldin, I., Cameron, G., \& Balarajan, M. (2011). Exceptional people: How migration shaped our world and will define our future. Princeton: Princeton University Press.

Halfmann, J. (2000). Welfare state and territory. In M. Bommes \& A. Geddes (Eds.), Immigration and welfare: Challenging the borders of the welfare state (pp. 34-50). London: Routledge.

Hmed, C. (2006). Loger les étrangers «isolés» en France. Socio-histoire d'une institution d'État: la Sonacotra (1956-2006). Unpublished doctoral thesis. Université de Paris 1 - Panthéon Sorbonne, Paris.

Hmed, C. (2007). Contester une institution dans le cas d'une mobilisation improbable : la « grève des loyers » dans les foyers Sonacotra dans les années 1970. Sociétés Contemporaines, 65, 55-81. http://doi.org/10.3917/soco.065.0055.

Itzigsohn, J. (2000). Immigration and the boundaries of citizenship: The institutions of immigrants' political transnationalism. International Migration Review, 34(4), 1126-1154. http:// doi.org/10.2307/2675977.

Jansen, S. (2007). Troubled locations: Return, the life course, and transformations of 'home' in Bosnia-Herzegovina. Focaal: European Journal of Anthropology, 49, 15-30. http://doi. org/10.3167/foc.2007.490103.

Kandel, W., \& Massey, D. S. (2002). The culture of Mexican migration: A theoretical and empirical analysis. Social Forces, 80(3), 981-1004.

King, R. (Ed.). (1986). Return migration and regional economic development: An overview. In Return migration and regional economic problems (pp. 1-37). London: Croom Helm. 
King, R. (2002). Towards a new map of European migration. International Journal of Population Geography, 8(2), 89-106. http://doi.org/10.1002/ijpg.246.

Kivisto, P. (2001). Theorizing transnational immigration: A critical review of current efforts. Ethnic and Racial Studies, 24(4), 549-577. http://doi.org/10.1080/01419870120049789.

Lacroix, T. (2005). Les réseaux marocains du développement: géographie du transnational et politique du territorial. Paris: Presses de Sciences Po.

Lacroix, T. (2013). Collective remittances and integration: North African and North Indian comparative perspectives. Journal of Ethnic and Migration Studies, 39(6):1019-1035.

Lallaoui, M. (1993). Du bidonville aux HLM. Paris: Syros.

Lévy-Vroelant, C. (2007). Les foyers de travailleurs migrants, une histoire complexe, une question encore aujourd'hui taboue. Cahiers Des Foyers, 1, 18-26.

Luhmann, N. (1977). Differentiation of society. The Canadian Journal of Sociology/Cahiers Canadiens de Sociologie, 2(1), 29-53. http://doi.org/10.2307/3340510.

Luhmann, N. (1990). Political theory in the welfare state. (J. Bednarz, Trans.). Berlin: Walter de Gruyter.

Luhmann, N. (1995). Social systems. (J. Bednarz \& D. Baecker, Trans.). Stanford: Stanford University Press.

MacMaster, N. (1993). Patterns of emigration, 1905-1954: 'Kabyles' and 'Arabs'. In A. G. Hargreaves \& M. J. Heffernan (Eds.), French and Algerian identities from colonial times to the present: A century of interaction (pp. 21-38). Lewiston: E. Mellen Press.

MacMaster, N. (1997). Colonial migrants and racism: Algerians in France, 1900-62. Basingstoke: Macmillan Press.

Manchuelle, F. (1997). Willing migrants: Soninke labor diasporas, 1848-1960. Athens: Ohio University Press.

Marcus, G. E. (1998). Ethnography through thick and thin. Princeton: Princeton University press.

Parry, O., Thomson, C., \& Fowkes, G. (1999). Life course data collection: Qualitative interviewing using the life grid. Sociological Research Online, 4(2.) http://www.socresonline.org.uk/4/2/ parry.html.

Peace, T. (2015). European social movements and Muslim activism: Another world but with whom? Basingstoke: Palgrave Macmillan.

Petauton, G. (2007). Histoire des luttes et des résistances. Cahiers Des Foyers, 1, $27-41$.

Pitti, L. (2008). 'Travailleurs de France, voilà notre nom'. Les mobilisations des ouvriers étrangers dans les usines et les foyers durant les années 1970. In A. Boubeker \& A. Hajjat (Eds.), Histoire politique des immigrations (post)coloniales: France, 1920-2008. Paris: Éditions Amsterdam.

Portes, A., Guarnizo, L. E., \& Landolt, P. (1999). The study of transnationalism: Pitfalls and promise of an emergent research field. Ethnic and Racial Studies, 22(2), 217-237. http://doi. org/10.1080/014198799329468.

Power, A. (1993). Hovels to high rise: State housing in Europe since 1850. London: Routledge.

Ramphele, M. (1993). A bed called home: Life in the migrant labour hostels of cape town. Cape Town: D. Philip.

Renaut, S. (2006). D’un recensement à l'autre : 1990-1999, la population immigrée en foyers de travailleurs. Retraite et Société, (47), 170-193.

Ridez, S., Colvez, A., \& Favier, F. (2001). Précarité des Maghrébins vieillissant dans les foyers Sonacotra. In P. Chauvin, F. Facy, M. Joubert, \& V. Ringa (Eds.), Précarisation, risque et santé (p. n. pag.). Montpelier: INSERM.

Roberts, B. (2002). Biographical research. Buckingham: Open University.

Rodríguez, V., \& Egea, C. (2006). Return and the social environment of Andalusian emigrants in Europe. Journal of Ethnic and Migration Studies, 32(8), 1377-1393. http://doi. org/10.1080/13691830600928771.

Sayad, A. (1977). Les trois 'âges' de l'émigration algérienne en France. Actes de la recherche en sciences sociales, 15(1), 59-79. http://doi.org/10.3406/arss.1977.2561.

Sayad, A. (2006). L'immigration ou Les paradoxes de l'alterité: Tome 1, L'illusion du provisoire (Vol. 1). Paris: Raisons d'agir. 
Schatz, E. (2009). Introduction: Ethnographic immersion and the study of politics. In E. Schatz (Ed.), Political ethnography: What immersion contributes to the study of power (pp. 1-22). Chicago: The University of Chicago Press.

Schutz, A. (1971). Collected papers (Vol. 2). The Hague: Nijhoff.

Sheffer, G. (2006). Transnationalism and ethnonational Diasporism. Diaspora: A Journal of Transnational Studies, 15(1), 121-145.

Silverstein, P. A. (2004). Algeria in France: Transpolitics, race, and nation. Bloomington: Indiana University Press.

Sinatti, G., \& Horst, C. (2015). Migrants as agents of development: Diaspora engagement discourse and practice in Europe. Ethnicities, 15(1), 134-152. https://doi.org/ $10.1177 / 1468796814530120$.

Soysal, Y. N. (1994). Limits of citizenship: Migrants and postnational membership in Europe. Chicago: University of Chicago.

Stark, O. (1991). The migration of labor. Oxford: Basil Blackwell.

Sun, K. C.-Y. (2016). Professional remittances: How ageing returnees seek to contribute to the homeland. Journal of Ethnic and Migration Studies, 42(14), 2404-2420. http://doi.org/10.108 0/1369183X.2016.1179106.

Thomas, W. I., \& Znaniecki, F. (1918). The polish peasant in Europe and America : Monograph of an immigrant group. Chicago: University of Chicago Press.

Timera, M. (1996). Les Soninké en France: d'une histoire à l'autre. Paris: KARTHALA Editions.

Union d'Economie Sociale pour le Logement. (2007). Document cadre relatif au plan de traitement des foyers de travailleurs migrants.

Viet, V. (1998). La France immigrée: Construction d'une politique, 1914-1997. Paris: Fayard.

Viet, V. (1999). La politique du logement des immigrés (1945-1990). Vingtième Siècle. Revue D'histoire, 64(1), 91-103. http://doi.org/10.2307/3770393.

Waldinger, R., \& Fitzgerald, D. (2004). Transnationalism in question. American Journal of Sociology, 109(5), 1177-1195.

Warnes, A. M., \& Williams, A. (2006). Older migrants in Europe: A new focus for migration studies. Journal of Ethnic and Migration Studies, 32(8), 1257-1281. http://doi. org/10.1080/13691830600927617.

Warnes, T. (2009). International retirement migration. In P. Uhlenberg (Ed.), International handbook of population aging (pp. 341-363). Dordrecht: Springer Netherlands.

Wengraf, T. (2000). Uncovering the general from within the particular. In P. Chamberlayne, J. Bornat, \& T. Wengraf (Eds.), The turn to biographical methods in social science: Comparative issues and examples (pp. 140-164). London: Routledge.

Open Access This chapter is licensed under the terms of the Creative Commons AttributionNonCommercial 4.0 International License (http://creativecommons.org/licenses/by-nc/4.0/), which permits any noncommercial use, sharing, adaptation, distribution and reproduction in any medium or format, as long as you give appropriate credit to the original author(s) and the source, provide a link to the Creative Commons license and indicate if changes were made.

The images or other third party material in this chapter are included in the chapter's Creative Commons license, unless indicated otherwise in a credit line to the material. If material is not included in the chapter's Creative Commons license and your intended use is not permitted by statutory regulation or exceeds the permitted use, you will need to obtain permission directly from the copyright holder.

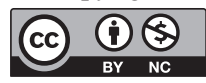

